\title{
Soil macrofauna in organic and conventional coffee plantations in Brazil
}

\author{
Janaina Biral dos Santos ${ }^{1}$, Alessandro Coutinho Ramos², Romildo Azevedo Júnior', \\ Luís Carlos Iuñes de Oliveira Filho ${ }^{3} \mathbb{E}$, Dilmar Baretta $^{4}$ \& Elke Jurandy Bran Nogueira Cardoso ${ }^{5 *}$ \\ ${ }^{1}$ Universidade de Vila Velha, Laboratório de Microbiologia Ambiental e Biotecnologia, Vila Velha, ES, Brasil \\ ${ }^{2}$ Universidade Estadual do Norte Fluminense, Laboratório de Fisiologia e Bioquímica, Campos dos \\ Goytacazes, RJ, Brasil \\ ${ }^{3}$ Universidade do Estado de Santa Catarina, Centro de Ciências Agroveterinárias, Lages, SC, Brasil \\ ${ }^{4}$ Universidade do Estado de Santa Catarina, Centro de Educação Superior do Oeste, Chapecó, SC, Brasil \\ ${ }^{5}$ Universidade de São Paulo, Escola Superior de Agricultura "Luiz de Queiroz”, Departamento de Ciência do \\ Solo, Piracicaba, SP, Brasil \\ *Corresponding author: Elke Jurandy Bran Nogueira Cardoso,e-mail: ejbncard@usp.br
}

\begin{abstract}
SANTOS, J. B., RAMOS, A. C., AZEVEDO JÚNIOR, R., OLIVEIRA FILHO, L. C. I., BARETTA, D., CARDOSO, E. J. B. N. Soil macrofauna in organic and conventional coffe plantations in Brazil. Biota Neotropica. 18(2): e20180515. http://dx.doi.org/10.1590/1676-0611-BN-2018-0515
\end{abstract}

\begin{abstract}
Brazil has always been one of the most important coffee producing countries. Lately, there has equally been a renewed interest in alternative coffee production systems. The state of Espírito Santo is the second greatest coffee producer in Brazil; so, we used local coffee plantations to evaluate the relations between soil macrofauna and chemical and microbiological soil properties to identify which of these properties discriminate more effectively between the organic management system (OS) and the conventional management system (CS) of coffee plantations. For each of these two cultivation systems we chose three coffee farms who employed both cultivation systems and picked out the most similar fields from each property. At each site, first we sampled the litter at the soil surface. Afterwards, we sampled nine soil monoliths to evaluate the macrofauna, in summer and winter. We also collected nine supplemental soil samples, taken at a few centimeters from the soil monoliths, for chemical and microbiological analyses. Macrofauna density was evaluated by ANOVA and multivariate analysis. The chemical and microbiological properties are environmental variables, while the data on macrofauna are the explanatory variables. The total number of individuals recovered in this study was 3,354, and the climate, identified by the sampling season, was a great modulator of macrofauna, with higher numbers in winter. The principal components analysis showed that soil moisture, organic matter, nitrogen, phosphorus, boron, copper, $\mathrm{pH}$, acid and alkaline phosphatases and microbial biomass carbon, were the most outstanding ones to discriminate both cultivation systems. We found no statistical significant differences in macrofauna density between OS and CS, probably due to a general great variability, since there was a tendency for much greater values in OS. We detected the interference of chemical and microbiological soil properties on the macrofauna community in both systems of coffee cultivation, and some results clearly correlated much better with climate data than with other factors. To our knowledge, this is the first time in which the data point to a clear separation between the more numerous and diversified soil macrofauna in coffee with organic cultivation from that with a conventional cultivation system.
\end{abstract}

Keywords: bioindicators, soil biology, soil ecology, soil fauna, climate.

\section{Macrofauna do solo em plantações de café orgânico e convencional no Brasil}

\footnotetext{
Resumo: O Brasil sempre foi um dos mais importantes países produtores de café. Ultimamente, houve um renovado interesse pelos sistemas alternativos de produção de café. O Estado do Espírito Santo é o segundo maior produtor de café do Brasil; então, utilizaram-se plantações locais de café para avaliar as relações entre a macrofauna do solo e as propriedades químicas e microbiológicas do solo para identificar quais dessas propriedades discriminam mais efetivamente entre o sistema de manejo orgânico (SO) e o sistema de manejo convencional (SC) das plantações de café. Para cada um desses dois sistemas de cultivo, escolheu-se três fazendas de café que empregaram ambos os
} 
sistemas de cultivo e selecionaram os campos mais similares de cada propriedade. Em cada local, primeiro amostrouse a serrapilheira do solo. Posteriormente, amostraram-se nove monólitos de solo para avaliar a macrofauna, tanto no verão como no inverno. Também, foram coletadas nove amostras suplementares de solo, a alguns centímetros dos monólitos de solo, para análises químicas e microbiológicas. A densidade da macrofauna foi avaliada por ANOVA e análise multivariada. As propriedades químicas e microbiológicas são variáveis ambientais, enquanto os dados sobre a macrofauna são as variáveis explicativas. O número total de indivíduos recuperados neste estudo foi de 3.354 e o clima, identificado pela época de amostragem, foi um ótimo modulador da macrofauna, com maiores números no inverno. A análise dos componentes principais mostrou que a umidade do solo, matéria orgânica, nitrogênio, fósforo, boro, cobre, $\mathrm{pH}$, fosfatases ácido e alcalina e carbono da biomassa microbiana, foram os mais destacados para discriminar ambos os sistemas de cultivo. Encontraram-se diferenças significativas na densidade da macrofauna entre SO e SC, provavelmente devido a uma grande variabilidade geral, uma vez que houve uma tendência para valores muito maiores no SO. Detectou-se a interferência das propriedades químicas e microbiológicas do solo na comunidade de macrofauna em ambos os sistemas de cultivo de café, e alguns resultados claramente correlacionados muito melhor com os dados climáticos do que com outros fatores. A nosso conhecimento, esta é a primeira vez em que os dados apontam para uma clara separação entre a macrofauna do solo mais numerosa e diversificada em café com cultivo orgânico de que com um sistema de cultivo convencional.

Palavras-chave: bioindicadores, biologia do solo, ecologia do solo, fauna do solo, clima.

\section{Introduction}

In Brazil, most of the Coffea sp. is cultivated on conventional systems. However, in recent years, the organic system has emerged and is creating a new market niche for organic products (Partelli et al. 2012). In the state of Espírito Santo, coffee (Coffea arabica L) is one of the most important agricultural products and affects social and economic scenarios (Frederico 2013). Coffee plantations are normally planted in monocultures and consequently may present a smaller biological diversity in the soil (Scherr \& McNeely 2008). Conventional agriculture requires high inputs of fossil energy and large amounts of fertilizers and chemical pesticides (Gündoğmuş 2006). This inputs often have a negative effect on soil quality, with a higher tendency to soil compaction, loss of mineral nutrients, and reduction of soil biota (Vasconcellos et al. 2013), which affect soil quality and ecological functions (Albrecht et al. 2010) and causes degradation of soil and environment. A more sustainable method of agriculture, that includes adoption of conservational practices, represents a feasible alternative for minimization of such effects (Partelli et al. 2016). Many biological processes are favored in organically managed farms (Glover et al. 2000), as higher root colonization by mycorrhizal fungi (Lamine \& Bellon 2009), constant transformation of organic materials, resulting in a greater stock of mineral nutrients and microbial activity (Scherr \& McNeely 2008). As reported by Bartz et al. (2009), in Brazil, few studies have been carried out to assess and compare the impact of organic and conventional systems on soil fauna populations under coffee plantations.

To evaluate the sustainability of a cultivation system, it is important to utilize good indicators of soil quality (Antunes et al. 2013, Cardoso et al. 2013, Azevedo Junior et al. 2017). These indicators must be sensitive to soil modifications, be part of the ecosystem functions, be easy to determine, easily understandable, and must be comparable with other indicators (Swift et al. 2004, Rousseau et al. 2013). Soil macrofauna complies with these characteristics in ecosystem functions, besides being part of different trophic levels, and show interactions with many environmental components, especially with plant residues, which constitute their major food resource and habitat (Swift et al. 2004).
Macrofauna are sensitive to modifications of the environment and rapidly respond to many different impacts on the ecosystem (Hole et al. 2005), while they are also important instruments to evaluate, organize and even modify soil (Rousseau et al. 2013).

Thus, one of the most important groups of soil macrofauna are earthworms (Oligochaeta). They affect soil structure, fertility and nutrient cycling with important consequences on plant growth (Lavelle \& Spain 2001, Bityutskii et al. 2016). They promote the distribution of particles and organic matter on the surface and in the soil profile, catalyzing microbial activity and consequently creating better conditions for colonization by other biotic components (Lavelle et al. 1999, Brown et al., 2000, Baretta et al. 2007). In agroecosystems, earthworms have positive impacts on plant production with an average increase in yield of $25-35 \%$, as reported in meta-analyses (Brown et al. 1999, van Groenigen et al. 2014). Since soil biodiversity is influenced by the cultivation systems adopted, information of the soil macrofauna and earthworms are important for success of agricultural activity and for sustainability.

There are physical and chemical soil properties that interact with macrofaunal groups by influencing their metabolism, while, at the same time, responding to the behavior of soil invertebrates. The most cited physical properties are soil texture, porosity, and water retention capacity, which normally are not susceptible to rapid responses, while the chemical ones are linked to soil fertility and nutrient availability (Effgen et al. 2008, 2012), and may have a great impact on soil macrofauna. Among the most responsive ones, we cite the microbiological properties, which describe the microbial activity in soils (Maluche-Baretta et al. 2006, Kaschuk et al. 2010). Partelli et al. (2016) and Azevedo Junior et al. (2017) highlight the positive effect of organic farming on physical attributes of soils. In coffee cultivation systems, according to Partelli et al. (2016), the physical properties, as soil resistance to penetration, macroporosity, density and total porosity in soil under organic management provides this system with a higher similarity to the Atlantic forest than the conventional system. Azevedo Junior et al. (2017) report that microbiological and chemical soil properties are effective in discriminating the two cultivation systems and 
most important as sensitive indicators were calcium, boron, microbial biomass carbon and acid phosphatase.

Up to now, in the State of Espírito Santo, there have been no reports or surveys on physical, chemical or biological indicators of soil health in organic or conventional coffee farms. Such studies are of importance to determine the sustainability of organic cultivation in relation to the conventional system. In this study, we focus on soil macrofauna for evaluating impacts of the agroecosystem management and on their use as potential biological indicators of soil quality. Equally, we focus too on earthworms as indicators of environmental quality, as they are sensitive to various soil and environmental modifications. We hypothesize that organic coffee cultivation systems provide chemical, physical and microbiological improvements of the soil, differentiating it from the conventionally cultivated soils, presenting greater sustainability and a greater abundance and diversity of soil organisms, especially of earthworms. Therefore, this study was set up in coffee plantations to identify which of the surveyed soil macrofauna groups and earthworms discriminate more effectively organic and conventional coffee plantations and to evaluate the relations between soil macrofaunal, as earthworms, indicators and chemical, physical and microbiological soil properties.

\section{Material and Methods}

\section{Characterization of the study site}

We conducted this research on indicators of soil quality at six sites with coffee farms, in the municipalities of Marechal Floriano $\left(20^{\circ} 26^{\prime}\right.$ $761^{\prime \prime} \mathrm{S}$ and $\left.40^{\circ} 45^{\prime} 780^{\prime \prime} \mathrm{W}\right)$, Domingos Martins (20 21' 572" S and $41^{\circ} 03$ '063" W), and Santa Maria de Jetibá (20 0' 267' S and 40 47' $010^{\prime}$ W), Espírito Santo State, Brazil. The three coffee plantations were 1 to 5 kilometers apart, and each farm presented plots under organic (OS) and conventional management (CS). Each plot was at least 1 ha in extension. Soils of these sites present a silty clay loam texture and are of lateritic origin, classified as Ferralsols (IUSS Working Group WRB 2015), with very similar nutrient availability, and an altitude between 700 and $1.000 \mathrm{~m}$, presenting conventional and organic coffee plantations closely together.

The climate of Marechal Floriano and Domingos Martins is subtropical of altitude, most of the time with average temperatures between $10^{\circ} \mathrm{C}$ and $18^{\circ} \mathrm{C}$ (Cwb, according to Köppen), typical of mountain ranges in tropical regions. During summer (in January 2013), the mean temperature was $23^{\circ} \mathrm{C}$ and the rainfall was $257 \mathrm{~mm}$ a month. In winter (in July 2013), the medium temperature was $18.5^{\circ} \mathrm{C}$ and the precipitation was $60 \mathrm{~mm}$ (registered at the Meteorological Experimental Station in Santa Maria (20 26' 761" S and 40 45' 780" W). Santa Maria de Jetibá presented a humid subtropical climate (Cwa). During summer, the mean rainfall is about $260 \mathrm{~mm}$ a month and, in winter, it varies from 60 to $80 \mathrm{~mm}$ a month. In this region we used the data of the Agro-climatic Station of Santa Teresa (19 98' $86^{\prime \prime}$ S and 40 57' 94" W), with average temperature of $21.2^{\circ} \mathrm{C}$ and average rainfall of $270 \mathrm{~mm}$ a month in summer. In winter the medium values were, respectively, $16.7^{\circ} \mathrm{C}$ and $81 \mathrm{~mm}$.

Each one of the chosen sites is a true repetition, as all of them were lying on similarly inclined slopes, at the western site, and the plantations were in the productive phase, over four years of age, planted with the variety Catuaí (IAC44). In OS, organic compost produced on the farm with chicken, cow or swine manure, mixed with fibrous plant material is applied at a rate of 3 to $4 \mathrm{~kg}$ of compost per plant once a year, in November or December. The farmers use $4 \%$ cow urine for pest control during winter. Herbicides are replaced by hoeing, and productivity is low, about 23 at $60 \mathrm{~kg}_{\text {bags ha-1 }}$. In CS, plants are fertilized with N-P-K (19-04-19), based on nitrate or ammonia, applying $200 \mathrm{~kg}$ per plant, three times a year. A foliar fertilizer composed of $4 \% \mathrm{~B}, 12 \% \mathrm{Cu}, 5 \%$ $\mathrm{Mn}, 5 \% \mathrm{Zn}, 1 \% \mathrm{~K}$ and $11 \%$ is sprayed on the shoots once a year, in November. Hemileia vastatrix Berkeley \& Broome 1869 (the pathogen of coffee rust) and Leucoptera coffeella (Guérin-Mèneville \& Perrottet 1842) (the leaf borer) are controlled with the fungicide Cyproconazole and the insecticide Thiamethoxan, while Glyphosate is the herbicide used. Productivity reaches 60 at $75 \mathrm{~kg}_{\text {bags ha }}{ }^{-1}$.

\section{Experimental design and soil sampling}

We sampled soil monoliths in summer (January 2013), and in winter (July 2013). For each system, we catalogued nine points in a grid sampling (centered in a 1 ha area), with a minimum distance of $30 \mathrm{~m}$ between them, to avoid autocorrelation, and leaving a border region of $20 \mathrm{~m}$ (Bartz et al. 2014). Sampling depth was always from 0 to $20 \mathrm{~cm}$, directly below the canopy of the coffee tree. Evaluation of the macrofaunal soil community was according to the methodology recommended by the "Tropical Soil Biology and Fertility" Program (TSBF) (Anderson \& Ingram 1993), which consists of sampling nine to ten soil monoliths measuring $625 \mathrm{~cm}^{2}$ and $20 \mathrm{~cm}$ deep per area studied. Previously, we sampled litter (including all plant residues on the soil surface) in an area of $1 \mathrm{~m}^{2}$. To obtain a representative soil sample for chemical, physical and microbiological analyses, at each of the nine points, directly at the sites where the soil monoliths were gathered, we also collected 0 to $20 \mathrm{~cm}$ deep soil subsamples, later mixed to provide a composite sample (Embrapa 1997, Tomé Jr. 1997). For physical (granulometry) and chemical analyses, soil samples were air-dried and sieved ( 2 mesh). To determine soil moisture, undisturbed samples were collected with the help of a volumetric ring, and stored inside a closed container. For microbiological analyses, soil samples were sieved (2 mesh) and stored in the refrigerator at $4{ }^{\circ} \mathrm{C}$ for analytical procedures.

\section{Soil Macrofauna Sampling}

The total of 27 soil monoliths were collected per system in each sample collection period. We define soil macrofauna as measuring 2 to $20 \mathrm{~mm}$, which includes more than 20 groups of invertebrates: Araneae, Blattodea, Coleoptera, Chilopoda, Diplopoda, Dermaptera, Formicidae (Hymenoptera), Gastropoda, Hemiptera, Isopoda, Isoptera, Oligochaeta, Opiliones, Orthoptera, Pseudoscorpionida, among others (sum of other less common groups, such as Homoptera, Lepidoptera, and some unidentified individuals) (Baretta et al. 2011). The macrofauna were hand-sorted from the monoliths and were stored in 70\% ethanol, except for the earthworms, stored in absolute alcohol. For identification, we visualized the macrofauna with a stereomicroscope, when necessary, and the taxonomical macrofaunal groups, defined at the level of class, order or family, were registered. Such higher level of arthropod taxonomy, and others invertebrates, is considered to provide benefits for rapid biodiversity surveys (Cotes et al. 2010, Gkisakis et al. 2016). It is mentioned as a particularly useful tool in the first phases of investigation for biodiversity assessments, at least at a local scale, comparing 
different land uses and agricultural management practices, when rapid results are required and financial resources are limited (Biaggini et al. 2007, Gkisakis et al. 2016). For earthworms, taxonomic classification was at the family level, and sometimes up to genus and species. All macrofaunal densities were assessed by counting individuals per square meter (ind. $\mathrm{m}^{-2}$ ) and by Shannon's Diversity index (Odum 1983, Santorufo et al. 2012) and earthworm diversity by richness (number of families, genera or species).

Specimens of this survey are housed at the Collection of the University of Vila Velha (UVV), Boa Vista, Vila Velha, Brazil.

\section{Chemical and physical soil analyses}

For the chemical analyses ( $\mathrm{pH}$, organic matter, $\mathrm{N}, \mathrm{P}, \mathrm{K}, \mathrm{Ca}, \mathrm{Mg}, \mathrm{S}$, $\mathrm{Al}, \mathrm{H}+\mathrm{Al}, \mathrm{Na}, \mathrm{CEC}$ at $\mathrm{pH} 7.0, \mathrm{Fe}, \mathrm{Cu}, \mathrm{Zn}, \mathrm{Mn}, \mathrm{B}$ ) and physical analyses (granulometry, moisture) we followed the methodology of van Raij et al. (2001) (Table 1). We quantified soil moisture twice, during summer and winter, while soil granulometrywas analyzed only once, in January 2013.

\section{Microbiological Soil Analyses}

Microbial biomass carbon (MBC) evaluation followed Vance et al. (1987), and $\mathrm{CO}_{2}$ evolution was according to Alef (1995) (Table 2). We calculated the metabolic quotient $\left(q \mathrm{CO}_{2}\right)$ according to Anderson \& Domsch (1993). The enzymes studied are involved in the biogeochemical cycles of phosphorus [acid (ACP) and alkaline (ALP) phosphatases] and were evaluated following Tabatabai \& Bremner (1969) (Table 2).

\section{Statistical analyses}

Prior to statistical analyses, total numbers of individuals for each taxonomic group were determined, and this value was the estimate of density (ind. $\left.\mathrm{m}^{-2}\right)$. Data (without outliers) were transformed $(\sqrt{ } \mathrm{x}+1)$ to comply with the requirements of analysis of variance (ANOVA; normal distribution and homoscedasticity of error variances). The normality of data (density) was checked with Kolmogorov-Smirnov's and homogeneity of variances was tested using Bartlett's test. ANOVA was the base to compare density of macrofauna community and Shannon's Diversity index in OS and CS in summer and winter, using SAS (SAS Institute 1999). Analyses were conducted at the farming system level, using the nine soil samples per municipality as replicates $(n=27$ in each farming system). Means presented in the text and figures were calculated using non-transformed data ( \pm standard deviation). Comparisons of means were according to Tukey's HSD test $(p<0.05)$. The same procedures were applied to OS earthworm specimens.

For multivariate analysis of the total number of individuals for each taxonomic group we obtained the length of the gradient in a detrended Correspondence Analysis and, as this was less than three (linear response), we opted for the Principal Components Analyses (PCA) using the software CANOCO 4.5 (ter Braak \& Šmilauer 2002). The collinear

Table 1. Chemical and physical characterization of the soils at a depth of $0-20 \mathrm{~cm}$ in the organic (OS) and conventional farming systems (CS), in the state of Espírito Santo, Brazil. ( $n=27$, means \pm standard deviation).

\begin{tabular}{|c|c|c|c|c|}
\hline \multirow{3}{*}{ Soil properties } & \multicolumn{4}{|c|}{ Cultivation systems } \\
\hline & \multicolumn{2}{|c|}{ Organic system } & \multicolumn{2}{|c|}{ Conventional system } \\
\hline & Summer & Winter & Summer & Winter \\
\hline Organic matter $\left(\mathrm{g} \mathrm{dm}^{-3}\right)$ & $50.77 \pm 3.75$ & $48.25 \pm 3.45$ & $42.56 \pm 1.80$ & $41.39 \pm 1.76$ \\
\hline $\mathrm{N}(\%)$ & $0.45 \pm 0.03$ & $0.49 \pm 0.03$ & $0.40 \pm 0.03$ & $0.40 \pm 0.03$ \\
\hline $\mathrm{Ca}\left(\mathrm{mmol} \mathrm{dm}{ }^{-3}\right)$ & $65.04 \pm 6.46$ & $57.07 \pm 5.58$ & $45.67 \pm 3.22$ & $41.11 \pm 2.54$ \\
\hline $\operatorname{Mg}\left(\mathrm{mmol} \mathrm{dm}^{-3}\right)$ & $16.52 \pm 0.89$ & $14.81 \pm 0.85$ & $12.627 \pm 1.04$ & $11.70 \pm 0.97$ \\
\hline $\mathrm{S}\left(\mathrm{mg} \mathrm{dm}^{-3}\right)$ & $33.63 \pm 2.71$ & $33.40 \pm 3.00$ & $33.77 \pm 2.22$ & $39.23 \pm 3.69$ \\
\hline $\mathrm{Al}\left(\mathrm{mmol} \mathrm{dm}{ }^{-3}\right)$ & $1.85 \pm 0.52$ & $1.37 \pm 0.50$ & $2.41 \pm 0.78$ & $1.19 \pm 0.43$ \\
\hline $\mathrm{Fe}\left(\mathrm{mg} \mathrm{dm}^{-3}\right)$ & $33.81 \pm 4.95$ & $35.09 \pm 5.39$ & $57.17 \pm 3.51$ & $48.58 \pm 4.05$ \\
\hline $\mathrm{Cu}\left(\mathrm{mg} \mathrm{dm}^{-3}\right)$ & $2.86 \pm 0.47$ & $1.79 \pm 0.39$ & $3.03 \pm 0.58$ & $2.19 \pm 0.38$ \\
\hline $\mathrm{Zn}\left(\mathrm{mg} \mathrm{dm}{ }^{-3}\right)$ & $20.59 \pm 3.36$ & $23.59 \pm 3.98$ & $13.04 \pm 0.90$ & $11.74 \pm 0.96$ \\
\hline $\operatorname{Mn}\left(\mathrm{mg} \mathrm{dm}^{-3}\right)$ & $27.24 \pm 2.98$ & $26.94 \pm 2.45$ & $10.47 \pm 0.88$ & $8.77 \pm 0.79$ \\
\hline $\mathrm{B}\left(\mathrm{mg} \mathrm{dm}^{-3}\right)$ & $0.36 \pm 0.03$ & $0.39 \pm 0.03$ & $0.54 \pm 0.02$ & $0.50 \pm 0.03$ \\
\hline Moisture (\%) & $22.71 \pm 0.90$ & $20.41 \pm 0.60$ & $20.61 \pm 0.35$ & $20.41 \pm 0.35$ \\
\hline Sand $\left(\mathrm{g} \mathrm{kg}^{-1}\right)$ & \multicolumn{2}{|c|}{$120.6 \pm 1.05$} & \multicolumn{2}{|c|}{$132.0 \pm 1.25$} \\
\hline Silt $\left(\mathrm{g} \mathrm{kg}^{-1}\right)$ & \multicolumn{2}{|c|}{$505.7 \pm 3.78$} & \multicolumn{2}{|c|}{$537.2 \pm 4.42$} \\
\hline Clay $\left(\mathrm{g} \mathrm{kg}^{-1}\right)$ & \multicolumn{2}{|c|}{$373.6 \pm 3.99$} & \multicolumn{2}{|c|}{$330.7 \pm 3.57$} \\
\hline
\end{tabular}

${ }^{1}$ CEC - Cation Exchange Capacity. 
Table 2. Microbiological characterization of the soils at $0-20 \mathrm{~cm}$ in organic (OS) and conventional farming system (CS), in the state Espírito Santo, Brazil. ( $\mathrm{n}=27$, means \pm standard deviation).

\begin{tabular}{|c|c|c|c|c|}
\hline \multirow{3}{*}{ Microbiological soil properties } & \multicolumn{4}{|c|}{ Cultivation systems } \\
\hline & \multicolumn{2}{|c|}{ Organic system (OS) } & \multicolumn{2}{|c|}{ Conventional system (CS) } \\
\hline & Summer & Winter & Summer & Winter \\
\hline Acid phosphatase activity $\left(\mathrm{mg}\right.$ PNF $\left.\mathrm{g}^{-1} \mathrm{~h}^{-1}\right)$ & $5.41 \pm 0.24$ & $5.56 \pm 0.27$ & $4.27 \pm 0.12$ & $4.71 \pm 0.20$ \\
\hline $\operatorname{MBC}\left(\mathrm{mg} \mathrm{C} \mathrm{g}^{-1} \text { dry soil }\right)^{2}$ & $0.62 \pm 0.02$ & $0.60 \pm 0.04$ & $0.46 \pm 0.01$ & $0.37 \pm 0.02$ \\
\hline
\end{tabular}

${ }^{1} \mathrm{PNF}$ - Phosphonitrophenol. ${ }^{2} \mathrm{MBC}-$ Microbial biomass carbon. ${ }^{3} \mathrm{CO}_{2}-\mathrm{C}-$ Basal respiration. ${ }^{4} q \mathrm{CO}_{2}-$ Metabolic coefficient.

and significant environmental attributes $(\mathrm{p} \leq 0.05)$ were identified by Redundancy Analysis (RDA), using Monte Carlos permutations, were subsequently used in the PCA as explanatory variables for changes in groups of soil macrofauna, comprehending soil moisture, $\mathrm{pH}, \mathrm{N}$, $\mathrm{P}, \mathrm{S}, \mathrm{Cu}, \mathrm{B}, \mathrm{OM}$ (organic matter), acid phosphatase (ACP), alkaline phosphatase (ALP), and microbial biomass carbon (MBC). This procedure guarantees a robust analysis (Baretta et al. 2010). The same procedures were followed for earthworms.

Afterwards, the environmental variables and macrofaunal groups were inserted into a Canonical Discriminant Analysis (CDA), to learn which of them was relevant in discriminating the cultivation systems (Baretta et al. 2005, 2010). Standardized canonical coefficients (SCC), correlation coefficients $(r)$, and parallel discrimination rates $(\mathrm{PDR}=$ $r \times$ SCC) were determined. PDR values indicate weight of each variable or property in discriminating the studied systems. Thus, values below 0.03 (class I) express a very low weight, from 0.04 to 0.09 (class II) a medium weight, between 0.10 and 0.20 (class III) they are considered good indicators, 0.21 to 0.41 (class IV) are very good, 0.42 to 0.80 (class V) are superior, while 0.81 and above (class VI) are excellent (Baretta et al. 2010). The $r$ coefficients reflect the individual role for each variable and the standardized canonical coefficient explains separation between the areas according to a multivariate point of view. Generally, PDR is the best one for identification of the weight for each property to discriminate the studied systems. If we find a significant difference of the systems by means of the CDA, we should use a comparison test of means of the SCC values in the canonical function I, using the LSD test $(\mathrm{p}<0.05)$.

\section{Results}

\section{Density and Shannon's Diversity index}

In total, 3,354 individuals were obtained in this study, and the most representative taxa were Oligochaeta, Coleoptera, Gastropoda, Hymenoptera, Isoptera and Chilopoda, regardless of cultivation system and season (Table 3).

Mean density of the organisms showed no significant variation between cultivation systems (Figure 1A). However, there was a significant difference between seasons in the organic system $(p=0.009)$, with a mean of $344 \pm 96$ ind. $\mathrm{m}^{-2}$ in summer and 1,323 \pm 707 ind. $\mathrm{m}^{-2}$ in winter. In CS, averages were 3.1 times smaller in summer (300 \pm 117 ind. $\left.\mathrm{m}^{-2}\right)$ than in winter $\left(916 \pm 859\right.$ ind. $\left.\mathrm{m}^{-2}\right)$. On the other hand, in both seasons, there were over 50\% more individuals in OS than in CS, although there was no statistical significance. Nevertheless, this is an indication of a strong tendency of OS to maintain greater numbers of macrofauna individuals, although a relatively great variation between replicates resulted in a lack of mathematical categorization.

Shannon's Diversity index of the organisms showed significant variation between cultivation systems in summer and winter and differences between seasons in the conventional system (Figure 1B).

\section{Principal Components Analysis (PCA) (macrofauna)}

The PCA on TSBF sampled macrofauna, in summer, showed that the two first principal components (PC1 and PC2) explain $64.4 \%$ of total variability of data, with $36.3 \%$ explained by $\mathrm{PC} 1$ and $28.1 \%$ by $\mathrm{PC} 2$.

For OS, in summer, there is greater diversity of organisms of the soil macrofauna than for conventional systems, as can be seen at the left of Figure 2A. One perceives a greater abundance of the different taxonomic groups associated with OS, especially due to higher values of chemical and microbiological properties and OS.

Oligochaeta correlated strongly with acid phosphatase (ACP) and nitrogen $(\mathrm{N})$. Dermaptera and Chilopoda correlated with organic matter, moisture and MBC. Isoptera, Coleoptera, Orthoptera, and some other groups correlate with alkaline phosphatase (ALP). Araneae, Hymenoptera, Hemiptera, Blattodea and Opiliones correlated with S, $\mathrm{P}$ and $\mathrm{pH}$. Finally, Gastropoda did not reveal any strong association with any chemical property (Figure 2A).

The organic system correlated with $\mathrm{OM}, \mathrm{N}, \mathrm{P}, \mathrm{S}, \mathrm{pH}$ and moisture, as well as with MBC, ACP and ALP. This seems to indicate that OS is a friendlier environment for a great many soil macrofaunal groups (Figure 2A). During summer, Diplopoda correlated with $\mathrm{B}$ and $\mathrm{Cu}$ in $\mathrm{CS}$, where we found smaller numbers of macrofauna (at the right in Figure 2A).

In winter, we also detected a greater diversity of soil macrofaunal groups in OS, when PCA explained $67.6 \%$ of total variability of data, with $43.9 \%$ for PC1 and $23.7 \%$ for PC2 (Figure 2B). Chemical soil properties $\mathrm{OM}, \mathrm{N}, \mathrm{P}, \mathrm{S}, \mathrm{pH}$, moisture and microbiological properties $\mathrm{MBC}, \mathrm{ACP}$ and ALP correlated with OS.

In winter, in OS, Isopoda, Diplopoda, Hemiptera and "others" (non-classified) correlated with $\mathrm{P}$ and $\mathrm{pH}$, while Gastropoda, Chilopoda, Blattodea, Hymenoptera, Oligochaeta, Isopoda, and Coleoptera correlated with MBC, ACP, ALP, N, OM and moisture. In CS, however, there was less correlation between macrofaunal groups and chemical properties. We only found some correlation between Araneae, Pseudoscorpionida and Opiliones with $\mathrm{Cu}, \mathrm{S}$ and $\mathrm{B}$ (Figure 2B). 
Santos, J. B. et al.

Table 3. Soil macrofauna (ind. $\mathrm{m}^{-2}$ ) sampled by TSBF in organic (OS) and conventional (CS) farming system in summer and winter, in Espírito Santo, Brazil.

\begin{tabular}{|c|c|c|c|c|}
\hline \multirow{2}{*}{ Soil macrofauna } & \multicolumn{2}{|c|}{ Summer } & \multicolumn{2}{|c|}{ Winter } \\
\hline & OS & CS & OS & CS \\
\hline Araneae & 32 & 160 & 64 & 112 \\
\hline Chilopoda & 112 & 32 & 1,232 & 128 \\
\hline Coleoptera & 544 & 176 & 672 & 384 \\
\hline Gastropoda & 96 & 64 & 2,336 & 256 \\
\hline Hemiptera & 80 & 80 & 16 & 0 \\
\hline Hymenoptera & 1,072 & 800 & 13,376 & 16,032 \\
\hline Isopoda & 0 & 0 & 192 & 32 \\
\hline Orthoptera & 32 & 0 & 0 & 0 \\
\hline Others $^{1}$ & 288 & 176 & 2,128 & 496 \\
\hline Pseudoscorpionida & 0 & 0 & 48 & 112 \\
\hline Total & 3,248 & 2,064 & 29,664 & 18,688 \\
\hline
\end{tabular}

${ }^{1}$ Others - Sum of other less common groups.
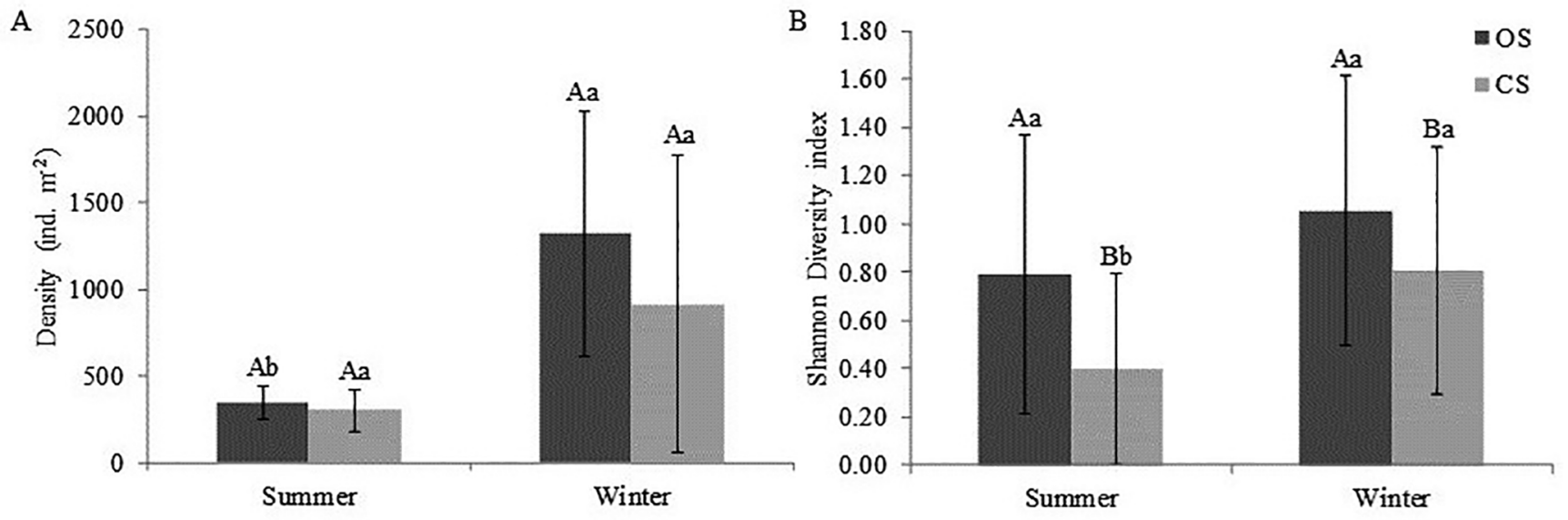

Figure 1. Average density and Shannon's Diversity index of the invertebrate macrofauna community in organic (OS) and conventional farming systems (CS) in two seasons, summer and winter, in Espírito Santo, Brazil. Means followed by the same capital letter for different farming systems, in the same season, do not differ by Tukey's test $(\mathrm{p}<0.05)$. Means followed by the same lower-case letter, comparing seasons in the same cropping system, do not differ by Tukey's test $(\mathrm{p}<0.05)$. $(\mathrm{T})$ Standard deviation $(\mathrm{n}=27)$.

\section{Canonical Discriminant Analysis (CDA) (Macrofauna)}

The Wilks'lambda test for macrofaunal richness and diversity revealed significant differences between management systems and between the seasons. We found high canonical correlations for summer $(0.66)$ and winter $(0.73)(\mathrm{p}<0.0001)$ of canonical discriminant functions 1 (CDF1) and 2 (CDF2); therefore, we performed a CDA for each sampling period.

The CDA explained part of the variability present in these cultivation systems regarding macrofauna. High correlation values indicate strong association between abundance of macrofaunal groups and cultivation systems. Standardized canonical coefficients (SCC) for CDF1 and for CDF2 explain the multivariate behavior of different soil macrofaunal groups, which discriminate between OS and CS as response to the independent variables, when analyzed together. CDF1 separated OS from CS (Figures 3A and 3B), and the differences between the SCC values and the centroids were smaller in winter. However, in both, summer and winter, there was no coincidence of the centroids for OS and CS. This polarized distribution of both cultivation systems indicates great dissimilarity regarding numbers of individuals for each soil macrofaunal group in OS and CS. 
A

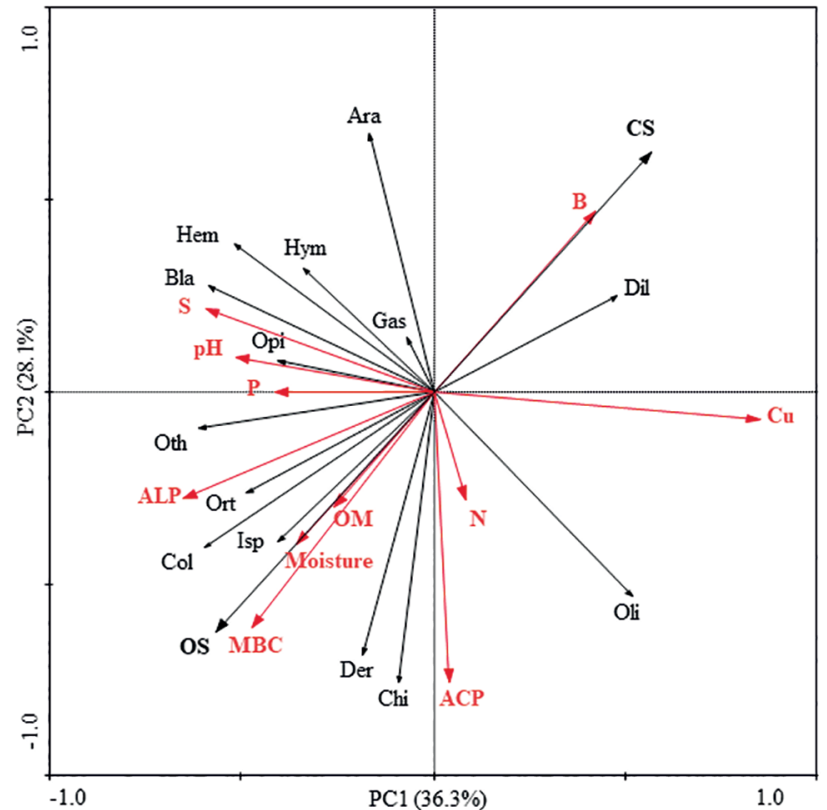

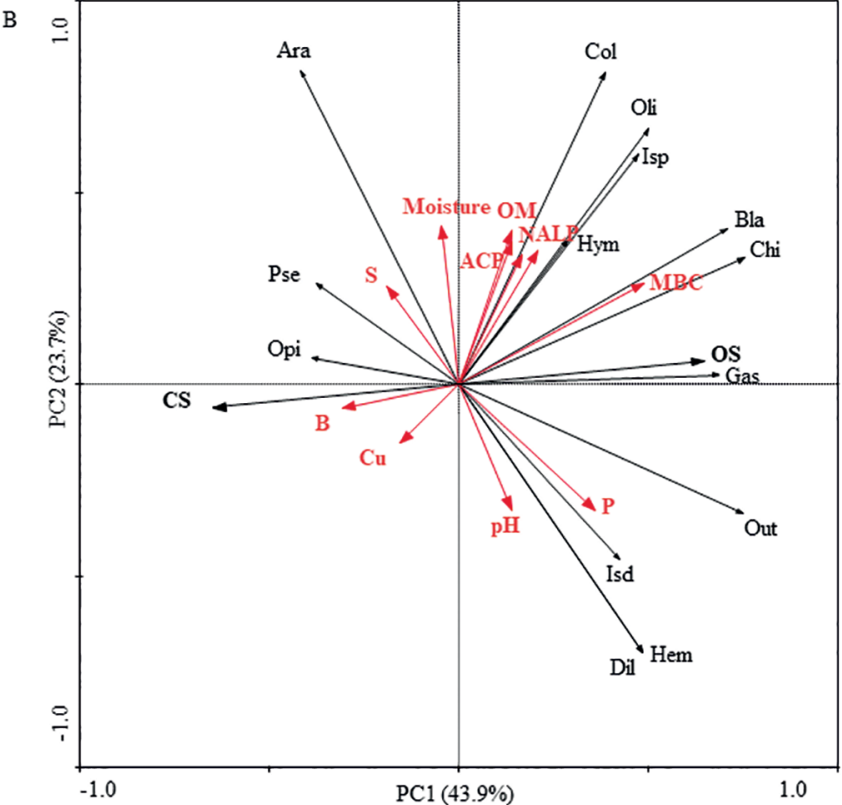

Figure 2. Relationship between the principal component 1 (PC1) and the principal component 2 (PC2), taking into account the organic (OS) and conventional farming system (CS), the invertebrate macrofauna community (black arrows) and the selected explicative environmental properties (red arrows) in summer (A) and winter (B), in Espírito Santo, Brazil. Oli: Oligochaeta, Dil: Diplopoda Ara: Araneae, Hym: Hymenoptera, Hem: Hemiptera, Bla: Blattodea, Gas: Gastropoda, Opi: Opiliones, Col: Coleoptera, Isd: Isopoda, Isp: Isoptera, Ort: Orthoptera, Pse: Pseudoscorpionida, Oth: Other, Der: Dermaptera, Chi: Chilopoda. Cu: copper, N: nitrogen, B: boron, S: sulfur, pH: hydrogen potential, P: phosphorus, ALP: alkaline phosphatase, ACP: acid phosphatase, OM: organic matter, MBC: microbial biomass carbon.

A

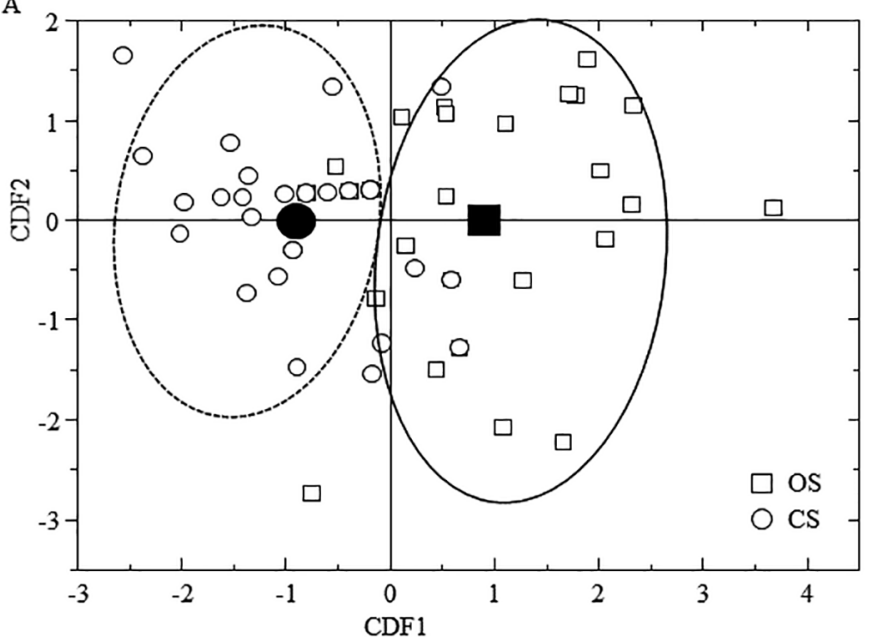

B

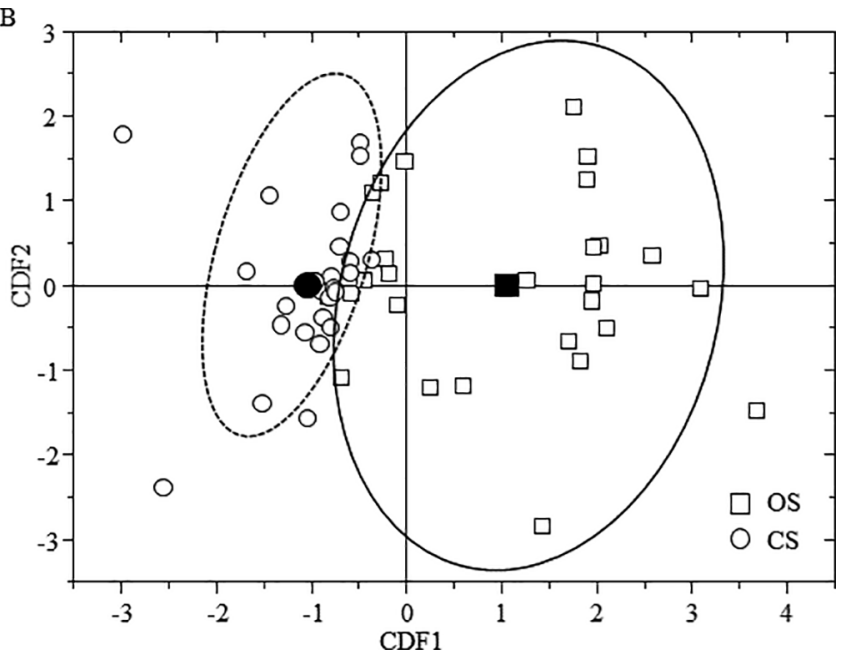

Figure 3. Relation between the first and second canonical discriminant function (CDF1 and CDF2) and the mean (centroid, in black) of the standardized canonical coefficients (CCP) for the studied environmental variables, discriminating organic (OS) and conventional farming system (CS), in summer (A) and winter (B), in Espírito Santo, Brazil.

Table 4 displays the potential of each soil macrofaunal property to discriminate soil quality, since they contribute the most for separation between cultivation systems. Positive PDR values indicate separation between systems, while negative values indicate similarities of the property between cultivating systems (Baretta et al. 2010). Orthoptera (0.32), Isoptera (0.24), Coleoptera (0.21) and Araneae (0.14) represent groups which contribute most to separate OS from CS in summer. In winter, among groups with the greatest potential to separate cultivation systems we find Gastropoda (0.45), Chilopoda (0.16) and Oligochaeta (0.13), respectively.

\section{Diversity of earthworms (Oligochaeta)}

Earthworm population density, in summer and winter, was higher in OS (59 and 26 ind. $\mathrm{m}^{-2}$, respectively) than in CS (13 and 14 ind. $\mathrm{m}^{-2}$, respectively) (Table 5). When comparing both sampling periods, within each system, there were differences only for OS (higher density in summer). It is worth noting that most earthworms found in the areas are juveniles, especially in winter samples. Excluding juvenile specimens, three species were present overall, being two in the OS systems and three in CS. CS had the highest species diversity in summer. Amynthas corticis was present only in CS and members of the family Megascolecidae 
Santos, J. B. et al.

Table 4. Parallel discrimination rates (PDR) calculated by multiplying the standardized canonical coefficients (SCC) and the correlation coefficients $(r)$ $(\mathrm{PDR}=r \times \mathrm{SCC})$ for groups sampled by TSBF in organic (OS) and conventional farming systems (CS) in summer and winter, in Espírito Santo, Brazil.

\begin{tabular}{|c|c|c|c|c|c|c|}
\hline \multirow{3}{*}{ Macrofauna groups } & \multicolumn{3}{|c|}{ CDF1 $^{1}$} & \multicolumn{3}{|c|}{ CDF1 } \\
\hline & \multicolumn{3}{|c|}{ Summer } & \multicolumn{3}{|c|}{ Winter } \\
\hline & $r$ & SCC & PDR & $r$ & SCC & PDR \\
\hline Blattodea & 0.41 & 0.22 & 0.09 & 0.02 & 0.30 & 0.01 \\
\hline Chilopoda & 0.32 & 0.26 & 0.08 & 0.39 & 0.42 & 0.16 \\
\hline Diplopoda & 0.21 & -0.16 & -0.03 & 0.37 & 0.13 & 0.05 \\
\hline Gastropoda & 0.15 & 0.07 & 0.01 & 0.80 & 0.56 & 0.45 \\
\hline Hemiptera & 0.02 & 0.00 & 0.00 & 0.31 & 0.13 & 0.04 \\
\hline Hymenoptera & -1.28 & 0.06 & -0.08 & -0.05 & -0.02 & 0.00 \\
\hline Opiliones & -0.52 & 0.00 & 0.00 & -0.25 & -0.24 & 0.06 \\
\hline Orthoptera & 1.44 & 0.23 & 0.32 & 0.00 & 0.00 & 0.00 \\
\hline Pseudoscorpionida & 0.00 & 0.00 & 0.00 & -0.13 & -0.16 & 0.02 \\
\hline Others $^{2}$ & -0.42 & 0.13 & -0.06 & 0.22 & 0.22 & 0.05 \\
\hline
\end{tabular}

${ }^{1} \mathrm{CDF}$ - Canonical Discriminant Functions. ${ }^{2}$ Others - Sum of other less common groups. Values in bold represent the most important macrofauna groups to discriminate areas of study.

Table 5. Earthworm species (ind. $\mathrm{m}^{-2}$ ) sampled by TSBF in organic (OS) and conventional farming systems (CS) in summer and winter, in Espírito Santo, Brazil.

\begin{tabular}{|c|c|c|c|c|c|}
\hline \multirow{2}{*}{ Family/Genus/Species } & \multirow{2}{*}{ Native/Exotic } & \multicolumn{2}{|c|}{ Summer } & \multicolumn{2}{|c|}{ Winter } \\
\hline & & $\mathbf{O S}^{2}$ & $\mathbf{C S}^{3}$ & OS & CS \\
\hline \multicolumn{6}{|l|}{ Glossoscolecidae } \\
\hline \multicolumn{6}{|l|}{ Megascolecidae } \\
\hline Megascolecidae (Family) & Exotic & 0 & 0 & 1.6 & 0 \\
\hline \multicolumn{6}{|l|}{ Acanthodrilidae } \\
\hline Dichogaster gracilis (Michaelsen, 1892) & Exotic & 4.8 & 1.6 & 0 & 0 \\
\hline Juveniles $^{4}$ & & 11.2 & 1.6 & 38.4 & 22.4 \\
\hline Total & & 94.4 & 20.8 & 41.6 & 22.4 \\
\hline
\end{tabular}

${ }^{1}$ Number of individuals converted to individuals $\mathrm{m}^{-2} .{ }^{2} \mathrm{OS}$ - Organic system. ${ }^{3} \mathrm{CS}$ - Conventional system. ${ }^{4}$ Young earthworms not possible to identify at the taxonomic level.

only in OS. Native species were not found neither in organic nor in conventional systems. All species found are peregrine or exotic.

\section{Principal Components Analysis (Oligochaeta)}

The PCA on earthworms sampled with TSBF, in summer, showed that the two first principal components (PC1 and PC2) explain $89.9 \%$ of the total variability of data, with $70.4 \%$ explained by $\mathrm{PC} 1$ and $14.5 \%$ by PC2 (Figure 4A). In summer, properties as moisture, OM, N, as well as ACP, ALP and MBC correlated more with OS, localized at the right side of the graph (Figure 4A). Acid phosphatase, OM, MBC, N and moisture were associated with P. corethrurus (Pcor), while ALP was associated preferentially with the juvenile earthworms. D. gracilis (Dgra) and individuals of the genus Amynthas sp. (Asp) showed association with $\mathrm{P}$ and with soil $\mathrm{pH}$. In opposition, the micronutrients $\mathrm{B}$ and $\mathrm{Cu}$ showed more association with $\mathrm{CS}$ and with the earthworm $A$. corticis.

In winter, the PCA explained $93.3 \%$ of the total variability of the data, with $74.5 \%$ for PC1 and $18.8 \%$ for PC2 (Figure $4 \mathrm{~B}$ ). In winter, OS and $\mathrm{CS}$ can be seen localized in the middle of the graph, quite different from what happened in summer; this demonstrates that changes in chemical and microbiological attributes occurred related to the seasons of the year (Figure 4B). Nevertheless, OS always correlated more with these soil attributes. The juvenile earthworms (Juv) and $P$. corethrurus 

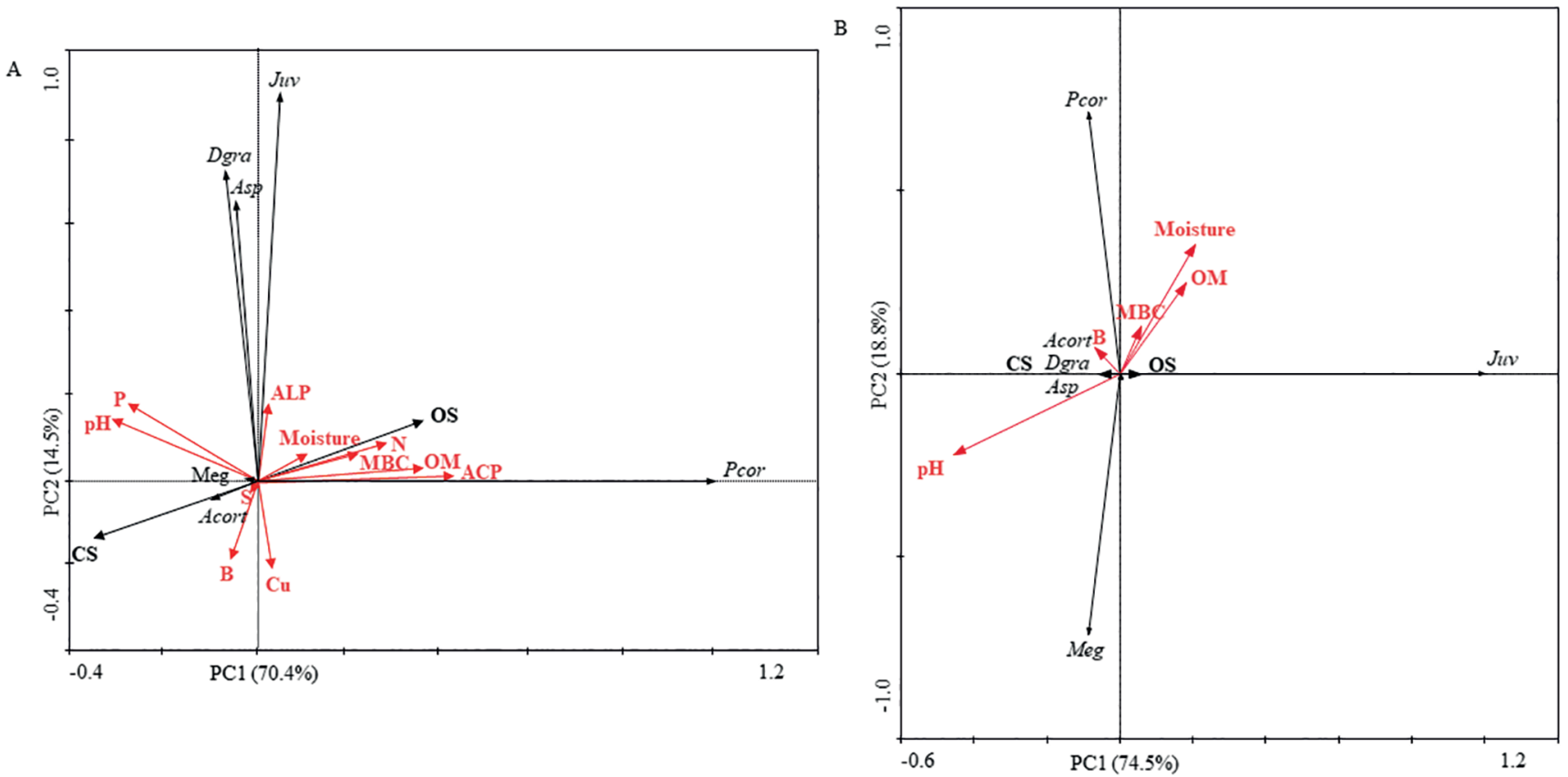

Figure 4. Relationship between the principal component 1 (PC1) and the principal component 2 (PC2), taking into account the organic (OS) and conventional farming system (CS), the earthworms $(\rightarrow)$ and the selected explicative environmental attributes $(\rightarrow)$ in summer (A) and winter (B), in Espírito Santo, Brazil. Acort: Amynthas corticis (Megascolecidae), Asp: Amynthas (Genus), Dgra: Dichogaster gracilis (Acanthodrilidae), Meg: Megascolecidae (Family), Pcor: Pontoscolex corethrurus. Cu: cupper, N: nitrogen, B: boron, S: sulfur, pH: hydrogen potential, P: phosphorus, ALP: alkaline phosphatase, ACP: acid phosphatase, OM: organic matter, MBC: microbial biomass carbon.

associated more with OM, moisture, and MBC in OS. Meanwhile the earthworms A. corticis (Acort), D. gracilis (Dgra) and other species of the genus Amynthas (Asp) assumed a more central position on the graph, without any close association with either one of the cultivation systems. $\mathrm{pH}$ correlated with earthworms of the family Megascolecidae.

\section{Discussion}

\section{Macrofauna}

In OS, we found a greater density of soil macrofauna in winter, a result that differs from most references in the literature, where the normal is to find a greater density in summer. Pimentel et al. (2011) report a greater density in coffee plantations in summer, while Fernandes et al. (2013) highlight a greater mobility of soil fauna in coffee plantations in the rainy season. Silva et al. (2012) mention that summer is more adequate for reproduction, resulting in a greater numbers of soil fauna community, so that most authors disagree from our results.

We assume that the organic management contributes to greater soil health and therefore presents greater ecological diversity and a greater functionality, since it avoids agricultural practices that have a negative impact on the environment (Rahmann 2011). Organic agricultural management produces a more heterogeneous, although stable environment, with greater nutritional equilibrium and with a greater offer of different foodstuffs for the soil macrofaunal community, as well as a greater number of habitats and ecological niches (Siegrist et al. 1998). For these reasons, somehow, it is natural to find a greater macrofaunal diversity in OS, although they do not completely explain the greater macrofaunal density in winter. In winter, obviously, the temperatures and rainfall were lower than in summer (Figure 1A), and these values lied below the optimum for the macrofaunal metabolism in winter. However, if considering the extreme dryness (see Material and Methods section 1 for climatic data - there was a steep decrease in precipitation, much more than in temperature during winter), it becomes understandable that OS, with much higher moisture in soil, can be more favorable for macrofaunal survival and even for reproduction during this period than CS. Thus, perhaps, we should not consider that soil conditions were optimal for macrofauna in OS during winter, but that they were worse in CS during this time. Teixeira et al. (2014) corroborate our study, since they report similar differences in macrofauna in an intercropped coffee plantation in another region of the state of Espírito Santo. Shannon's indices follow the same reasoning and confirm that the organic system provides greater diversity of macrofauna groups, showing higher means in both seasons (Figure 1). We attribute the increase of this index in winter for CS to a smaller temperature oscillation.

Oligochaeta sometimes is one of the most abundant taxonomic groups of soil macrofauna in agriculture (Lebbink et al. 1994, Zwart et al. 1994, Bartz et al. 2013, Rosa et al. 2015), however, in our research, the number of earthworms found was rather small, although the low number is partially compensated by their relatively greater weight. Reasons for these differences may be due to the natural and anthropogenic history of the areas, and the presence/absence of exotic or invasive species (Decaëns et al. 2004).

A fact that possibly contributed to the greater abundance of macrofauna in OS is that, shortly before sampling, the OS soils received organic compost incorporation. Some earthworm species are also 
important for the distribution and incorporation of organic materials into soil, what may have contributed to an overall increase in macrofauna, because of better access to energetic food sources and to moisture (Mäder et al. 2002, Masto et al. 2008).

In OS, we identified the presence of Orthoptera and Dermaptera only in summer, and Isopoda and Pseudoscorpionida only in winter (Figure 2). All these groups are important members of the food chain for OM degradation in soil (Bird et al. 2000, Morón-Ríos et al. 2010, Ponce et al. 2011).

Results of PCA and CDA (Figure 2 and Table 4, respectively) suggest that the micronutrients $\mathrm{Cu}$ and $\mathrm{B}$ may have been a limiting factor for macrofauna, especially for earthworms, in CS. Some pesticides used in coffee plantations in $\mathrm{CS}$ have $\mathrm{Cu}$ in their composition, and increased amounts of this element may cause negative impacts on earthworms and many other soil invertebrates. In minimum tillage and conventional coffee plantations, respectively, Zaller et al. (2014) and Bartz et al. (2009) report some evidence of detrimental effects of the herbicide glyphosate and of copper-based fungicides on earthworms.

Microbial biomass carbon is one of the most responsive properties to the organic cultivation and often there is a close similarity between MBC values in OS and in the Atlantic Forest in Brazil (Partelli et al. 2012). There are reports on increases of MBC in organic cultivation systems, and considered to be very important for OS, as highlighted by other authors (Maluche-Baretta et al. 2006). In CS, however, as shown by the PCA, there was a positive correlation with mineral nutrients, $\mathrm{B}$ in summer and $\mathrm{Cu}$ and B in winter. Silva et al. $(2012,2013)$ and Ferreira et al. (2013) report an increase of soil $\mathrm{pH}$ up to 6.5 in coffee plantations under OS, which coincides with our results (Table 1). Several other authors detected an increase of soil CEC, $\mathrm{P}, \mathrm{MBC}$ and $\mathrm{pH}$ in organic coffee plantations (Pimentel et al. 2006, Fernandes et al. 2013).

In OS, there was also a correlation with $\mathrm{P}$, and it is quite common to find greater $\mathrm{P}$ availability, probably related to an increase in acid and alkaline phosphatases (Nannipieri et al. 2012), while in CS, with systematic applications of mineral fertilizers and pesticides, we find an inhibition of phosphatase activities (Nannipieri et al. 2011, 2012). Generally, soil OM, clay content and moisture correlate with OS, and these correlate with soil fertility in coffee plantations (Silva \& Lima 2013, Machado et al. 2014). As a rule, OS also has higher numbers of macrofauna when compared with CS. Soil under long-term OS usually presents better properties for coffee plantations, in comparison with CS (Velmourougane 2016) and has higher values for most of the biological properties, including higher populations of Oligochaeta (Lammel et al. 2015).

Regardless of the sample collection period, we observed, through PDR values, that macrofauna was effective in separating the areas studied, showing potential as indicators. Baretta et al. (2010) also found positive values of PDR coefficients for Chilopoda, Isoptera and Pereira et al. (2017) found for Chilopoda, Oligochaeta and Gastropoda, considered an indicator of changes in natural and replanted areas with Araucaria. The other groups of macrofauna were less sensitive, with lower values of PDR, and they contributed less to the function recommended for separation between the areas (Table 2). This result confirms recommendation this groups, besides Araneae, Coleoptera, Orthoptera, as important in discriminating between organic and conventional systems, because they provided separation between the areas.

\section{Oligochaeta}

In conventional agricultural systems with the highest use intensity, earthworm communities often are harmed directly by the aggressive tillage practices or indirectly through decreases in food supply (Falco et al. 2015). OS coffee plantations resulted in an evident increase of earthworm abundance when compared to CS; thus, Bartz et al. (2009) found higher numbers and diversity of adult and juvenile earthworms in organic coffee plantations in winter (July). In our study, we found greater adult earthworm density in summer, whereas, in winter, there was a greater contribution of juveniles in both cultivation systems (Table 5), showing the importance of the addition of young specimens to the edaphic community.

The abundance of earthworm communities greatly decreased between the two sampling seasons in OS, while in CS it remained the same (Table 5). The climatic conditions may be prone to explain these results. Considering the influence of rainfall for soil moisture and total abundance of earthworms in the systems, there was a possible effect of rainfall on temporal changes between the two periods (Figure 1A). Rainfall may have been less beneficial for earthworms in the CS than in OS, probably because the latter was able to hold a much greater water volume (Pelosi et al. 2015).

No doubt, history of the areas and chemical and physical properties (Table 1) influenced distribution of earthworms and dominance of $P$. corethrurus in OS. Since use of pesticides affects presence of earthworms, this may partially explain their rarity in CS. Two earthworm species, P. corethrurus (soil feeding) and A. corticis (litter feeding), were recorded in shaded coffee plantations without glyphosate-based herbicide treatment, whereas the latter species was absent from plots with glyphosate-based herbicides (García-Pérez et al. 2014), however, in our research, the only individual of the species $A$. corticis was detected in CS (Table 5).

In our study, fertilizer and pesticide applications and variations in organic matter input could have contributed to the differences found in earthworm densities between organic and conventional systems (Tables 1 and 2). In fact, differences found in earthworm density would be attributable to fertilization and pesticides, which varied between treatments (Sánchez-de León et al. 2006). Organic management practices are particularly favorable for increasing $P$. corethrurus and Amynthas sp. populations (Bartz et al. 2009). Aquino et al. (2008), when surveying earthworm populations, also found great diversity, including $P$. corethrurus, which is an exotic and cosmopolitan species. The presence of other exotic species, as A. corticis and D. gracilis, as well as some specimens of the family Megascolecidae and of the genus Amynthas may represent a problem at the ecological level, because these organisms are well distributed and very adaptable to different environments, posing a risk to the survival of native species (Brown et al. 2006). In intensive agricultural management, the earthworm community is mainly composed of exotic species given their adaptability (Fragoso 2001, Grosso et al. 2006). Dominance of introduced species is another characteristic of highly disturbed sites (Winsome et al. 2006, Chan \& Barchia 2007). In both evaluated coffee cultivation systems exotic earthworm species predominated, and this may pose a risk to the survival of native species however this a generalized fact in Brazilian agricultural soils. Soil use intensity is also a probable mechanism to explain the presence of a few species (e.g. P. corethrurus, A. corticis, D. gracilis), adapted to a great environmental variability (Falco et al. 2015). 
Soil attributes measured in the present study are known to affect abundance of earthworm species; the relatively pronounced variation from organic to conventional systems (Table 1), likely had an influence on the variation in earthworm species abundance, added to differences in soil physical attributes (e.g., bulk density), which could help to explain this variation. We recognize that the role of environmental variability as predictor of organism diversity and abundance varies with the scale of ecological studies (Ettema \& Wardle 2002). Soil use intensity was also a probable mechanism to explain the presence of a few species (e.g. $P$. corethrurus, $A$. corticis, $D$. gracilis), adapted to a great environmental variability (Falco et al. 2015).

\section{Conclusions}

The study provided significant data on the soil arthropod community of the organic and conventional management system adopted in coffee and its relationship with management and soil properties. Abundance of macrofauna groups suffers relatively little influence of the agricultural management system adopted in coffee cultivation, but OS provided greater diversity of taxonomic groups than CS. The soil macrofauna groups Oligochaeta, Coleoptera, Gastropoda, Hymenoptera, Isoptera and Chilopoda were most abundant in organic cultivation systems. Chemical and microbiological soil attributes interfere on the communities of soil fauna organisms in soil.

In coffee plantations, earthworms are good indicators and discriminate between the organic and conventional cultivation system, and both systems has a dominance of exotic earthworm.

Multivariate statistical analyses, as principal components analysis and canonical discriminant analysis, are adequate tools to evaluate ecological parameters in coffee agroecosystems. The application of the PDR coefficient, which is a result of the CDA, has proved to be a powerful tool for the selection of soil quality indicators, and the most promising properties for separation between the areas with coffee plantations were Araneae, Chilopoda, Coleoptera, Gastropoda, Isoptera, Oligochaeta e Orthoptera.

\section{Acknowledgements}

J. B. dos Santos thanks the Espírito Santo Research Support and Innovation Foundation (FAPES) for a post-graduate research grant. E. J. B. N. Cardoso and D. Baretta acknowledges a research grant from the Brazilian Research Council (CNPq). We thank L. F. Baldesin and P. R. Alves, both of the University of São Paulo, Brazil, for their help with the chemical analyses and providing references on coffee plantations, respectively. Our gratefulness to M. L. C. Bartz of the University Positivo, in Paraná, for help with the taxonomy of the earthworms.

\section{Authors' Contributions}

Janaina Biral dos Santos: responsible for sampling of macrofauna and for data collection, contributed to manuscript preparation, critical revision, and adding intellectual content.

Alessandro Coutinho Ramos and Romildo Azevedo Júnior: helped in defining areas and in sampling. The first one was co-responsible for the general outline of the research project, while the second assisted with laboratory procedures, data collection, and preparation of figures.
Luís Carlos Iuñes de Oliveira Filho: contribution to data analysis and interpretation, contribution to critical revision, adding intellectual content.

Dilmar Baretta and Elke Jurandy Bran Nogueira Cardoso: substantial contribution in the concept and design of the study, contribution to data analysis and interpretation, contribution to manuscript preparation, contribution to critical revision, adding intellectual content.

\section{Conflicts of interest}

The authors declare that they have no conflict of interest related to the publication of this manuscript.

\section{References}

ALBRECHT, M., SCHIMID, B., OBRIST, M.K., SCHÜPBACH, B., KLEIJN, D. \& DUELLI, P. 2010. Effects of ecological compensation meadows on arthropod diversity in adjacent intensively managed grassland. Biol. Conserv. 143:642-649.

ALEF, K. 1995. Soil respiration. In Methods in Applied Soil Microbiology and Biochemistry (K. Alef \& P. Nannipieri, eds.). Academic Press, London, p.234-245.

ANDERSON, J.M. \& INGRAM, J.S.I. 1993. Tropical Soil Biology and Fertility: A Handbook on Methods, 2 ed. CAB International, Wallingford.

ANDERSON, T.H. \& DOMSCH, K.H. 1993. The metabolic quotient for $\mathrm{CO}_{2}$ $\left(q \mathrm{CO}_{2}\right)$ as a specific activity parameter to assess the effects of environmental conditions, such as $\mathrm{pH}$, on the microbial biomass of forest soils. Soil Biol Biochem. 25:393-395.

ANTUNES, S.C., CASTRO, B.B., MOREIRA, C., GONÇALVES, F. \& PEREIRA, R. 2013. Community-level effects in edaphic fauna from an abandoned mining area: integration with chemical and toxicological lines of evidence. Ecotoxicol. Environ. Saf. 88:65-71.

AQUINO, A.M., MELOVIRGÍNIO FILHO, E., RICCI, M.S.F. \& CASANOVES, F. 2008. Populações de minhocas em sistemas agroflorestais com café convencional e orgânico. Cienc. agrotec. 32:1184-1188.

AZEVEDO JUNIOR, R.R., SANTOS, J.B., BARETTA, D., RAMOS, A.C. \& CARDOSO, E.J.B.N. 2017. Chemical and microbiological soil properties in organic and conventional management systems of Coffea arabica L. J. Plant Nutr. 40:2076-2086.

BARETTA, D., BROWN, G.G. \& CARDOSO, E.J.B.N. 2010. Potencial de la macrofauna y de otras variables edáficas como indicadoras de la calidad del suelo en áreas con Araucaria angustifolia. Acta Zool. Mex. 26, 135-150.

BARETTA, D., BROWN, G.G., JAMES, S.W. \& CARDOSO, E.J.B.N. 2007. Earthworm populations sampled using collection methods in Atlantic forests with Araucaria angustifolia. Sci. Agric. 64:384-392.

BARETTA, D., SANTOS, J.C.P., FIGUEIREDO, S.R. \& KLAUBERG-FILHO, O. 2005. Efeito do monocultivo de Pinus e da queima do campo nativo em atributos biológicos do solo no Planalto sul Catarinense. Rev. Bras. Cienc. Solo 29:715-724

BARETTA, D., SANTOS, J.C.P., SEGAT, J.C., GEREMIA, E.V., OLIVEIRA FILHO, L.C.I. \& ALVES, M.V. 2011. Fauna edáfica e qualidade do solo. In Tópicos em Ciência do Solo (O. Klauberg-Filho, Á.L. Mafra \& L.C. Gatiboni, eds.). Sociedade Brasileira de Ciência do Solo, Viçosa, p.119-170.

BARTZ, M.L.C., BROWN, G.G., PASINI, A., FERNANDES, J.D.O., CURMI, P., DORIOZ, J. \& RALISCH, R. 2009. Earthworm communities in organic and conventional coffee cultivation. Pesq. agropec. bras. 44:928-933.

BARTZ, M.L.C., BROWN, G.G., ROSA, M.G., KLAUBERG FILHO, O., JAMES, S.W., DECAËNS, T. \& BARETTA, D. 2014. Earthworm richness in land-use systems in Santa Catarina, Brazil. Appl. Soil Ecol. 83:59-70.

BARTZ, M.L.C., PASINI, A. \& BROWN, G.G. 2013. Earthworms as soil quality indicators in Brazilian no-tillage systems. Appl. Soil Ecol. 69:39-48. 
BIAGgINI, M., CONSORTI, R., DAPPORTO, L., DELlACASA, M., PAGGETTI, E. \& CORTI, C. 2007. The taxonomic level order as a possible tool for rapid assessment of Arthropod diversity in agricultural landscapes. Agric. Ecosyst. Environ. 122:183-191.

BIRD, S., COULSON, R.N. \& CROSSLEY JR., D.A. 2000. Impacts of silvicultural practices on soil and litter arthropod diversity in a Texas pine plantation. For. Ecol. Manage. 131:65-80.

BITYUTSKII, N., KAIDUN, P. \& YAKKONEN, K. 2016. Can earthworms alleviate nutrient disorders of plants subjected to calcium carbonate excess? Appl. Soil Ecol. 98:20-29.

BROWN, G., PASHANASI, B., VILLENAVE, C., PATRÓN, J.C., SENAPATI, B., GIRI, S., BAROIS, I., LAVELLE, P., BLANCHART, E., BLAKEMORE, R.J., SPAIN, A.V. \& BOYER, J. 1999. Effects of earthworms on plant production in the tropics. In Earthworm Management in Tropical Ecosystems (P. Lavelle, L. Brussaard \& P.F. Hendrix, eds.). CABI, Wallingford, p.87-147.

BROWN, G.G., BAROIS, I. \& LAVELLE, P. 2000. Regulation of soil organic matter dynamics and microbial activity in the drilosphere and the role of interactions with other edaphic functional domains. Eur. J. Soil Biol. $36: 177-198$

BROWN, G.G., JAMES, S.W., PASINI, A., NUNES, D.H., BENITO, N.P., MARTINS, P.T. \& SAUTTER, K.D. 2006. Exotic, peregrine, and invasive earthworms in Brazil: Diversity, distribution, and effects on soils and plants. Caribb. J. Sci. 42:339-358.

CARDOSO, E.J.B.N., VASCONCELLOS, R.L.F., BINI, D., MIYAUCHI, M.Y.H., SANTOS, C.A., ALVES, P.R.L., PAULA, A.M., NAKATANI, A.S., PEREIRA, J.M. \& NOGUEIRA, M.A. 2013. Soil health: looking for suitable indicators. What should be considered to assess the effects of use and management on soil health? Sci. Agric. 70:274-289.

CHAN, K.Y. \& BARCHIA, I., 2007. Soil compaction controls the abundance, biomass and distribution of earthworms in a single dairy farm in southeastern Australia. Soil Tillage Res. 94:75-82.

COTES, B., CAMPOS, M., PASCUAL, F., GARCÍA, P.A. \& RUANO, F. 2010. Comparing taxonomic levels of epigeal insects under different farming systems in Andalusian olive agroecosystems. Appl. Soil Ecol. 44:228-236.

DECAËNS, T., JIMÉNEZ, J.J., BARROS, E., CHAUVEL, A., BLANCHART, E., FRAGOSO, C. \& LAVELLE, P. 2004. Soil macrofaunal communities in permanent pastures derived from tropical forest or savanna. Agric. Ecosyst. Environ. 103:301-312.

EFFGEN, T.A.M., PASSOS, R.R., ANDRADE, F.V., LIMA, J.S.S., REIS, E.F. \& BORGES, E.N. 2012. Propriedades físicas do solo em função de manejos em lavouras de cafeeiro Conilon. Rev. Ceres 59:414-421.

EFFGEN, T.A.M., PASSOS, R.R., LIMA, J.S.S., BORGES, E.N., DARDENGO, M.C.J.D. \& REIS, E.F. 2008. Atributos químicos do solo e produtividade de lavouras de cafeeiro Conilon submetidas a diferentes tratos culturais no sul do estado do Espírito Santo. Biosci. J. 24:7-18.

EMBRAPA - Empresa Brasileira de Pesquisa Agropecuária 1997. Manual de métodos de análise de solo. Embrapa Solos, Rio de Janeiro.

ETTEMA, C.H. \& WARDLE, D.A. 2002. Spatial soil ecology. Trends Ecol. Evol. 17:177-183.

FALCO, L.B., SANDLER, R., MOMO, F., DI CIOCCO, C., SARAVIA, L. \& COVIELLA, C. 2015. Earthworm assemblages in different intensity of agricultural uses and their relation to edaphic variables. PeerJ 3:e979.

FERNANDES, A.L.T., SANTINATO, F., FERREIRA, R.T. \& SANTINATO, R. 2013. Adubação orgânica do cafeeiro, com uso do esterco de galinha, em substituição à adubação mineral. Coffee Sci. 8:486-499.

FERREIRA, J.T.P., FERREIRA, E.P., OLIVEIRA, M.L., SILVA, G.S., OLIVERIA FILHO, J.S. \& SANTOS, J.W.G. 2013. Avaliação da fertilidade dos solos cultivados com café Conilon (Coffea canephora) no município de Santa Teresa - ES. Encicl. Biosf. 9: 356-366.

FRAGOSO, C. 2001. Las lombrices de tierra de México (Annelida, Oligochaeta): diversidad, Ecología y manejo. Acta Zool. Mex. 131-171.

FREDERICO, S. 2013. Cafeicultura Científica Globalizada e as Montanhas Capixabas: a produção de café Arábica nas regiões do Caparaó e Serrana do Espírito Santo. Rev. Soc. Nat. 25:7-20.
GARCÍA-PÉREZ, J.A., ALARCÓN-GUTIÉRREZ, E., PERRONI, Y. \& BAROIS, I. 2014. Earthworm communities and soil properties in shaded coffee plantations with and without application of glyphosate. Appl. Soil Ecol. 83: 230-237.

GKISAKIS, V., VOLAKAKIS, N., KOLLAROS, D., BÀRBERI, P. \& KABOURAKIS, E.M. 2016. Soil arthropod community in the olive agroecosystem: Determined by environment and farming practices in different management systems and agroecological zones. Agric. Ecosyst. Environ. 218:178-189.

GLOVER, J.D., REGANOLD, J.P. \& ANDREWS, P.K. 2000. Systematic method for rating soil quality of conventional, organic, and integrated apple orchards in Washington State. Agric. Ecosyst. Environ. 80:29-45.

GROSSO, E., JORGE, G. \& BROWN, G.G. 2006. Exotic and Native Earthworms in Various Land Use Systems of Central, Southern and Eastern Uruguay. Caribb. J. Sci. 42:294-300.

GÜNDOĞMUŞ, E. 2006. Energy use on organic farming: A comparative analysis on organic versus conventional apricot production on small holdings in Turkey. Energ. Convers. Manage. 47:3351-3359.

HOLE, D.G., PERKINS, A.J., WILSON, J.D., ALEXANDER, I.H., GRICE, P. V. \& EVANS, A.D. 2005. Does organic farming benefit biodiversity? Biol. Conserv. 122:113-130.

IUSS WORKING GROUP WRB 2015. World Reference Base for Soil Resources 2014, update 2015 International soil classification system for naming soils and creating legends for soil maps. World Soil Resources Reports No. 106. FAO, Rome, p.203.

KASCHUK, G., ALBERTON, O. \& HUNGRIA, M. 2010. Three decades of soil microbial biomass studies in Brazilian ecosystems: Lessons learned about soil quality and indications for improving sustainability. Soil Biol. Biochem. 42:1-13.

LAMINE, C. \& BELLON, S. 2009. Conversion to Organic Farming: A Multidimensional Research Object at the Crossroads of Agricultural and Social Sciences - A Review. Sustain. Agric. 29:97-112.

LAMMEL, D.R., AZEVEDO, L.C.B., PAULA, A.M., ARMAS, R.D., BARETTA, D. \& CARDOSO, E.J.B.N. 2015. Microbiological and faunal soil attributes of coffee cultivation under different management systems in Brazil. Brazilian J. Biol. 75:894-905.

LAVELLE, P., PASHANASI, B., CHARPENTIER, F., GILOT, C., ROSSI, J.P., DEROUARD, L., ANDRE, J., PONGE, J.F. \& BERNIER, N. 1999. Largescale effects of earthworms on soil organic matter and nutrient dynamics. In Earthworm Ecology (C.A. Edwards, ed.). St. Lucie Press, Boca Raton, p.103-122.

LAVELLE, P. \& SPAIN, A.V. 2001. Soil Ecology. 1 ed. Kluwer Scientific, Amsterdam.

LEBBINK, G., VAN FAASSEN, H.G., VAN OUWERKERK, C. \& BRUSSAARD, L. 1994. The Dutch Programme on Soil Ecology of Arable Farming Systems: Farm management monitoring programme and general results. Agric. Ecosyst. Environ. 51:7-20.

MACHADO, L.V., RANGEL, O.J.P., MENDONÇA, E.S., MACHADO, R.V. \& FERRARI, J.L. 2014. Fertilidade e compartimentos da matéria orgânica do solo sob diferentes sistemas de manejo. Coffee Sci. 9:2897-299.

MÄDER, P., FLIESSBACH, A., DUBOIS, D., GUNST, L., FRIED, P. \& NIGGLI, U. 2002. Soil fertility and biodiversity in organic farming. Science 296:1694-1697.

MALUCHE-BARETTA, C.R.D., AMARANTE, C.V.T. \& KLAUBERG FILHO, O. 2006. Análise multivariada de atributos do solo em sistemas convencional e orgânico de produção de maçãs. Pesq. agropec. bras. 41:1531-1539.

MASTO, R.E., CHHONKAR, P.K., SINGH, D. \& PATRA, A.K. 2008. Changes in soil quality indicators under long-term sewage irrigation in a sub-tropical environment. Environ. Geol. 56:1237-1243.

MOHAMEDOVA, M. \& LECHEVA, I. 2013. Effect of heavy metals on microarthropod community structure as an indicator of soil ecosystem health. Sci. P. Series A. Agron. LVI:73-78. 
MORÓN-RÍOS, A., RODRÍGUEZ, M.Á., PÉREZ-CAMACHO, L. \& REBOLLO, S. 2010. Effects of seasonal grazing and precipitation regime on the soil macroinvertebrates of a Mediterranean old-field. Eur. J. Soil Biol. 46:91-96.

NANNIPIERI, P., GIAGNONI, L., LANDI, L. \& RENELLA, G. 2011. Role of Phosphatase Enzymes in Soil. In Phosphorus in Action: Biological Processes in Soil Phosphorus Cycling (E.K. Bünemann, A. Oberson \& E. Frossard, eds.). Springer-Verlag Berlin Heidelberg, Berlin, p.215-243.

NANNIPIERI, P., GIAGNONI, L., RENELLA, G., PUGLISI, E., CECCANTI, B., MASCIANDARO, G., FORNASIER, F., MOSCATELLI, M.C. \& MARINARI, S. 2012. Soil enzymology: classical and molecular approaches. Biol. Fertil. Soils 48:743-762.

ODUM, E.P. 1983. Ecologia. 1 ed., Guanabara, Rio de Janeiro.

PARTELLI, F.L., VIEIRA, H.D., FERREIRA, E.P. DE B., VIANA, A.P., MARTINS, M.A. \& URQUIAGA, S. 2012. Chemical and Microbiological Soil Characteristics under Conventional and Organic Coffee Production Systems. Commun. Soil Sci. Plant Anal. 43:847-864.

PARTELLI, F.L., VALICHESKI, R.R., VIEIRA, H.D., GONTIJO, I., \& BRITO FERREIRA, E.P. 2016. Physical soil attributes of conilon coffee (Coffea canephora) under organic and conventional management systems. Aust. J. Crop Sci. 10(5):646-653.

PELOSI, C., BERTRAND, M., THÉNARD, J. \& MOUGIN, C. 2015. Earthworms in a 15 years agricultural trial. Appl. Soil Ecol. 88:1-8.

PIMENTEL, M.S., AQUINO, A.M., ELIZABETH, M., CORREIA, F., COSTA, J.R., FREIRE, S. \& DE-POLLI, H. 2006. Atributos biológicos do solo sob manejo orgânico de cafeeiro, pastagem e floresta em região do médio Paraíba Fluminense-RJ. Coffee Sci. 1:85-93.

PIMENTEL, M.S., DE-POLLI, H., AQUINO, A.M. DE, CORREIA, M.E.F. \& ROUWS, J.R.C. 2011. Bioindicators of soil quality in coffee organic cultivation systems. Pesq. agropec. bras. 46:545-552.

PONCE, C., BRAVO, C., DE LEÓN, D.G., MAGAÑA, M. \& ALONSO, J.C. 2011. Effects of organic farming on plant and arthropod communities: A case study in Mediterranean dryland cereal. Agric. Ecosyst. Environ. 141:193-201.

RAHMANN, G. 2011. Biodiversity and organic farming: What do we know? Agric. For. Res. 3:189-208.

ROSA, M.G., KLAUBERG FILHO, O., BARTZ, M.L.C., MAFRA, Á.L., SOUSA, J.P.F.A. \& BARETTA D. 2015. Macrofauna edáfica e atributos físicos e químicos em sistemas de uso do solo no Planalto Catarinense. Rev. Bras. Cienc. Solo. 39:1544-1554.

ROUSSEAU, L., FONTE, S.J., TÉLlEZ, O., VAN DER HOEK, R. \& LAVELLE, P. 2013. Soil macrofauna as indicators of soil quality and land use impacts in smallholder agroecosystems of western Nicaragua. Ecol. Indic. 27:71-82.

SÁNCHEZ-DE LEÓN, Y., DE-MELO, E., SOTO, G., JOHNSON-MAYNARD, J. \& LUGO-PÉREZ, J. 2006. Earthworm Populations, Microbial Biomass and Coffee Production in Different Experimental Agroforestry Management Systems in Costa Rica. Caribb. J. Sci. 42:397-409.

SANTORUFO, L., VAN GESTEL, C.A.M., ROCCO, A. \& MAISTO, G. 2012. Soil invertebrates as bioindicators of urban soil quality. Environ. Pollut. 161:57-63.

SAS INSTITUTE 1999. SAS/STAT: User's Guide Statistics. SAS Institute, Cary.

SCHERR, S.J. \& MCNEELY, J.A. 2008. Biodiversity conservation and agricultural sustainability: towards a new paradigm of "ecoagriculture" landscapes. Philos. Trans. R. Soc. Lond. B. Biol. Sci. 363:477-94.
SIEGRIST, S., SCHAUB, D., PFIFFNER, L. \& MÄDER, P. 1998. Does organic agriculture reduce soil erodibility? The results of a long-term field study on loess in Switzerland. Agric. Ecosyst. Environ. 69:253-264.

SILVA, J., JUCKSCH, I. \& TAVARES, R.C. 2012. Invertebrados edáficos em diferentes sistemas de manejo do cafeeiro na Zona da Mata de Minas Gerais. Rev. Bras. Agroecol. 7:112-125.

SILVA, S.A. \& LIMA, J.S.S. 2013. Atributos físicos do solo e sua relação espacial com a produtividade do café arábica. Coffee Sci. 8:395-403.

SILVA, V.M., TEIXEIRA, A.F.R., REIS, E.F., BENASSI, A.C. \& MENDONÇA, E.S. 2013. Atributos químicos do solo em sistemas de adubação orgânica de Conilon. Coffee Sci. 8:469-477.

SWIFT, M.J., IZAC, A.-M.N. \& VAN NOORDWIJK, M. 2004. Biodiversity and ecosystem services in agricultural landscapes-are we asking the right questions? Agric. Ecosyst. Environ. 104:113-134.

TABATABAI, M.A. \& BREMNER, J.M. 1969. Use of p-nitrophenyl phosphate for assay of soil phosphatase activity. Soil Biol. Biochem. 1:301-307.

TEIXEIRA, A.F.R., SILVA, V.M. \& MENDONÇA, E.S. 2014. Fauna edáfica em sistemas arborizados de café conilon em solo de tabuleiros costeiros. Coffee Sci. 9:385-393.

TER BRAAK, C.J.F. \& ŠMILAUER, P. 2002. CANOCO Reference Manual and CanoDraw for Windows User's Guide: Software for Canonical Community Ordination (Version 4.5). Microcomputer Power, Wageningen.

TOMÉ JR, J.B. 1997. Manual para interpretação de análises de solo. Agropecuária, Guaíba.

VAN GROENIGEN, J.W., LUBBERS, I.M., VOS, H.M., BROWN, G.G., DE DEYN, G.B. \& VAN GROENIGEN, K.J. 2014. Earthworms increase plant production: a meta-analysis. Sci. Rep. 4:6365

VAN RAIJ, B., ANDRADE, J.C., CANTARELLA, H. \& QUAGGIO, J.A. 2001. Análise química para avaliação da fertilidade de solos tropicais. Instituto Agronômico de Campinas, Campinas.

VANCE, E.D., BROOKES, P.C. \& JENKINSON, D.S. 1987. An extraction method for measuring soil microbial biomass C. Soil Biol. Biochem. 19:703-707.

VASCONCELLOS, R.L.F., SEGAT, J.C., BONFIM, J.A., BARETTA, D. \& CARDOSO, E.J.B.N. 2013. Soil macrofauna as an indicator of soil quality in an undisturbed riparian forest and recovering sites of different ages. Eur. J. Soil Biol. 58:105-112.

VELMOUROUGANE, K. 2016. Impact of Organic and Conventional Systems of Coffee Farming on Soil Properties and Culturable Microbial Diversity. Scientifica. 2016:1-9.

WINSOME, T., EPSTEIN, L., HENDRIX, P.F. \& HORWATH, W.R. 2006. Competitive interactions between native and exotic earthworm species as influenced by habitat quality in a California grassland. Appl. Soil Ecol. $32: 38-53$.

ZALLER, J.G., HEIGL, F., RUESS, L. \& GRABMAIER, A. 2014. Glyphosate herbicide affects belowground interactions between earthworms and symbiotic mycorrhizal fungi in a model ecosystem. Sci. Rep. 4:5634.

ZWART, K.B., BURGERS, S.L.G.E., BLOEM, J., BOUWMAN, L.A., BRUSSAARD, L., LEBBINK, G., DIDDEN, W.A.M., MARINISSEN, J.C.Y., VREEKEN-BUIJS, M.J. \& RUITER, P.C. 1994. Population dynamics in the belowground food webs in two different agricultural systems. Agric. Ecosyst. Environ. 51:187-198. 